\title{
Az 1-es és 2-es típusú diabéteszes kardiális diszfunkció hátterében álló eltérō miokardiális szövettani és molekuláris jellegzetességek
}

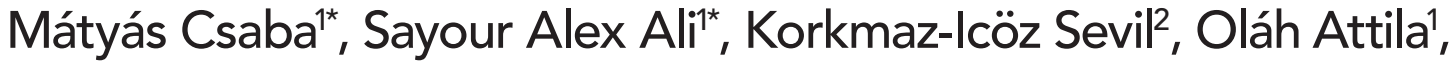 \\ Németh Balázs Tamás ${ }^{1}$, Páli Szabolcs ${ }^{1,2}$, Hirschberg Kristóf ${ }^{2}$, Zubarevich Alina², \\ Gwanmesia Patricia Neh², Li Shiliang'2, Loganathan Sivakkanan², \\ Barnucz Enikő"1, 2 , Merkely Béla1, Szabó Gábor², Radovits Tamás', 2
}

\author{
${ }^{1}$ Semmelweis Egyetem, Városmajori Szív- és Érgyógyászati Klinika, Kísérleti Kutató Laboratórium, Budapest \\ ${ }^{2}$ Ruprecht-Karls Egyetem, Szívsebészeti Klinika, Kísérleti Kutató Laboratórium, Heidelberg, Németország
}

Levelezési cím: Dr. Radovits Tamás, 1122 Budapest, Városmajor u. 68. E-mail: radovitstamas@yahoo.com

\begin{abstract}
Célkitűzés: A cukorbetegség (diabetes mellitus, DM) a szívizomzat strukturális és funkcionális elváltozásához vezet. Jelen tanulmányunkban az 1-es és a 2-es típusú DM-ben kialakuló diabéteszes cardiomyopathiához társuló funkcionális és szubcelluláris patológiai változások összehasonlító vizsgálatát végeztük el.

Módszerek: 1-es típusú DM-et streptozotocinnal indukáltunk. 2-es típusú DM modellként Zucker Diabetic Fatty (ZDF) patkányokat használtunk. A kardiális funkció megítélésére bal kamrai nyomás-térfogat analízist végeztünk. Emellett miokardiális nitrotirozin immunohisztokémiát, TUNEL, hematoxilin-eozin, illetve Masson trikróm festést végeztünk. A különböző mRNS és proteinek expresszióját qRT-PCR-rel és Western blot technikákkal vizsgáltuk.

Eredmények: Az 1-es típusú DM-ben megfigyelhető jelentős szisztolés diszfunkció erőteljes oxidatív stresszel, apoptózissal és fibrózissal társult. 2-es típusú DM-ben mindezek az elváltozások kevésbé voltak kifejezettek vagy teljesen hiányoztak, miközben hasonló mértékű cardiomyocyta-hipertrófia volt megfigyelhető a diasztolés falmerevség növekedése és megtartott szisztolés funkció mellett. 1-es típusú DM-ben emelkedett a hipertrófia marker c-fos, c-jun és $\beta$-MHC és a pro-apoptotikus kaszpáz-12 mRNS expressziója, míg 2-es típusban nem vagy kevéssé változtak. A profibrotikus TGF- $\beta 1$ génexpressziója fokozódott 1-es, ugyanakkor csökkent 2-es típusú DM-ben.

Következtetések: Jelen vizsgálatunkban a diabéteszes szív megváltozott patofiziológiai tulajdonságait és azok funkcionális hatását írtuk le 1-es és 2-es típusú DM patkánymodelljeinkben.
\end{abstract}

Kulcsszavak: diabetes mellitus, T1DM, T2DM, kardiális diszfunkció, diabéteszes cardiomyopathia

An altered pattern of myocardial histopathological and molecular changes underlies the different characteristics of type-1 and type-2 diabetic cardiac dysfunction

Aims: Increasing evidence suggests that both types of diabetes mellitus (DM) lead to cardiac structural and functional changes. In this study we investigated and compared functional characteristics and underlying subcellular pathological features in rat models of type-1 and type-2 diabetic cardiomyopathy.

Methods: Type-1 DM was induced by streptozotocin. For type-2 DM, Zucker-diabetic fatty (ZDF) rats were used. Left ventricular pressure-volume analysis was performed to assess cardiac function. Myocardial nitrotyrosine immunohistochemistry, TUNEL-assay, hematoxylin-eosin and Masson's trichrome staining were performed. mRNA and protein expression were quantified by qRT-PCR and Western blot.

Results: Marked systolic dysfunction in type-1 DM was associated with severe oxidative stress, apoptosis and fibrosis. These pathological features were less pronounced or absent, while cardiomyocyte hypertrophy was comparable in type-2 DM, which was associated with unaltered systolic function and increased diastolic stiffness. mRNA-expression of hypertrophy markers c-fos, c-jun and $\beta-M H C$, as well as pro-apoptotic caspase-12 were elevated in type-1, while remained unaltered or only slightly increased in type-2 DM. Expression of the profibrotic TGF- $\beta 1$ was upregulated in type-1 and showed a decrease in type-2 DM. Conclusions: We compared type-1 and type-2 diabetic cardiomyopathy in standard rat models, described an altered pattern of key pathophysiological features in the diabetic heart and corresponding functional consequences.

Keywords: diabetes mellitus, T1DM, T2DM, cardiac function, diabetic cardiomyopathy 


\section{Bevezetés}

Patomechanizmustól függően 1-es és 2-es típusú diabetes mellitust (DM) különböztethetünk meg. Jól ismert, hogy 2-es típusú diabéteszre (T2DM) jellemző a hyperinsulinaemia, hyperglykaemia és dyslipidaemia. Ezzel szemben 1-es típusú diabétesz (T1DM), a Langerhans-szigetek béta-sejtjeinek autoimmunitás közvetítette károsodása miatt csökkent inzulinszinttel és hyperglykaemiával társul. Emellett a T1DM hirtelen kezdetü, míg T2DM esetén a hyperglykaemiás állapotot megelőzi egy euglykaemiás, egyre fokozódó inzulinrezisztenciával, illetve hyperinsulinaemiával járó periódus. Bár a cukorbetegek mortalitását leginkább a szívkoszorúerek ateroszklerózisa határozza meg, bizonyítékok szólnak amellett, hogy léteznek DM-indukált, a myocardiumot közvetlenül érintő strukturális és funkcionális elváltozások (1). A diabéteszes cardiomyopathia kialakulása a cukorbetegség mindkét formájában jelen van, amelyet a szívizomzat módosult sejtszintü anyagcseréjének tulajdonítanak, és amely megnöveli a szívelégtelenség kialakulásának kockázatát (2).

Évtizedeken keresztül a diabéteszes cardiomyopathiával kapcsolatos kutatásokat a „standardnak” számító és széleskörüen alkalmazott streptozotocin-(STZ) indukálta T1DM állatmodellen végezték. Mindazonáltal a klinikai gyakorlatban a cukorbetegek túlnyomó többsége T2DM-ben szenved ettől eltérő kórélettani háttérrel. Ennek következtében számos T2DM állatmodell jelent meg az utóbbi években (3-5).

Kutatócsoportunk korábban publikálta az 1-es (STZ-indukálta) és 2-es (Zucker Diabetic Fatty [ZDF] patkányok) típusú DM patkánymodelljeinek részletes hemodinamikai jellemzését.

T1DM és T2DM között jelentős különbséget találtunk a kardiális diszfunkció karakterisztikájában.

- T1DM-ben csökkent szisztolés teljesítményt és megnyúlt kamrai relaxációt,

- míg T2DM-ben a bal kamra (BK) megnövekedett falmerevségét találtuk (6).

A diabéteszes cardiomyopathia kialakulásának kórélettani háttere és szubcelluláris mechanizmusai nem teljesen feltártak. Az anyagcsere abnormalitása, továbbá a reaktív oxigén (ROS) és nitrogén-származékok termelődése számos jelátviteli út kóros aktiválódását válthatja ki így módosítva különböző gének miokardiális expresszióját. A miokardiális nitro-oxidatív stressz, a szívizomzat hipertrófiás és fibrotikus remodellációja az apoptózis fokozódásával együtt mind kritikus szerepet játszik a cardiomyopathia kialakulásában a DM mindkét típusa esetében (7-9).

Fentiek alapján, további vizsgálatok szükségesek a diabéteszes myocardiumra jellegzetes molekuláris, sejtszintű és funkcionális elváltozások karakterisztikájával kapcsolatban T1DM, illetve T2DM-ben. Jelen kutatásunkban célul tűztük ki a myocardium szövettani és molekuláris változásainak vizsgálatát, amelyek a bal kamra jellegzetes eltéréseinek hátterében állhatnak T1DM és T2DM állatmodelljeiben $(6,10)$.

\section{Eszközök és módszerek}

Állatok

Vizsgálatainkat a kísérleti állatok tartásáról és felhasználásáról szóló nemzetközi szabályoknak (Guide for the Care and Use of Laboratory Animals, US National Institutes of Health 1996; 85-23.) megfelelően végeztük. Sprague-Dawley (SD) és ZDF patkányainkat (Charles River, Németország) standard laboratóriumi körülmények között tartottuk.

T1DM-et streptozotocinnal (STZ, $60 \mathrm{mg} / \mathrm{kg}$, ip. citrát oldatban oldva) indukáltunk SD-patkányokban $(n=8)$. A kontrollállatok a vivőanyagot kapták $(n=10) .72$ órával az STZ injekció után meghatároztuk a vércukorszintet. A >15 mmol// random vércukorszinttel rendelkező állatokat diabéteszesnek tekintettük és bevontuk a tanulmányba. A vizsgálatokat az ezt követő 8 . héten hajtottuk végre (6).

A ZDF patkányokban genetikai mutáció és speciális diéta révén alakul ki a cukorbetegség és annak szövődményei. A homozigóta recesszív állatokban (fa/fa) elhízás, magas vércukorszint és T2DM fejlődik ki (ZDF-csoport, $\mathrm{n}=8)$. A homozigóta domináns $(+/+)$ és a heterozigóta „lean” genotípusú állatok normoglykaemiásak maradnak (ZDF lean csoport, $n=9$ ). A vizsgálatokat az állatok 30-32 hetes korában végeztük el (6).

Vizelet- és vércukorszintek meghatározása A hemodinamikai mérések előtt a farokvénából vett vérből digitális vércukormérő segítségével határoztuk meg a vércukorszintet, majd a feldolgozás során nyert vizeletmintákból tesztcsíkkal mutattuk ki a vizelet glükóztartalmát.

\section{Hemodinamikai mérések}

A patkányokat ip. ketamin-xilazin (100; 3 mg/kg) injekcióval elaltattuk, majd tracheotomiát és intubációt követően mesterségesen lélegeztettük, testhőmérsékletüket fütőpad segítségével $37^{\circ} \mathrm{C}$-on tartottuk. Ezt követően egy 2Fr-es nyomás-konduktancia mikrokatétert vezettünk a BK-ba. Regisztráltuk a BK-i nyomás-térfogat (PV) viszonyokat és változó előterhelés mellett meghatároztuk az ejekciós frakciót (EF) és a végszisztolés $P V$ öszszefüggés meredekségét (ESPVR), amelyek szisztolés paraméterek. A BK-falmerevséget a BK-i végdiasztolés nyomás (LVEDP) és a végdiasztolés $P V$ összefüggés meredeksége (EDPVR) alapján számoltuk ki (11).

\section{Szövettan és immunhisztokémia}

Paraformaldehid (4\%-os oldat) fixációt majd paraffinos beágyazást követően a bal kamrai szívizomszövet metszetek hematoxillin-eozin (HE) és Masson trikróm (MT) festését végeztük. A HE-metszeteken fénymikroszkóppal 100 darab BK-i szívizomsejt transzverzális transz- 
nukleáris szélességét (cardiomyocyta átmérő, KD) mértük le metszetenként. A miokardiális kollagén szintet az MT-festés szemikvantitatív morfometriai pontozásával határoztuk meg a következők alapján: 0 (hiányos), 1 (enyhe), 2 (közepes), 3 (intenzív). Az átlagértéket a BK 20 véletlenszerűen kiválasztott látómezőjének pontértékéből számoltuk.

Emellett a BK-i metszeteken a nitro-oxidatív stressz-marker 3-nitrotirozin (NT) immunhisztokémiai festését is elvégeztük (12). A metszeteken a festés intenzitását és eloszlását szemikvantitatív módon értékeltük. Valamennyi metszeten 4 egymás melletti látóteret értékeltünk, amelyet a következőképpen pontoztunk: 0 (immunreaktivitás teljes hiánya); 1 (enyhe területi festődés); 2 (közepes festődés) és 3 (erős festődés). Az NT-pozitív területeket szoftverrel kvantifikáltuk, majd hozzájuk rendeltünk egy területi pontszámot (1 $\leq 10 \%$ pozitív sejt; $2=11-50 \%$; $3=51-80 \%$ és $4 \geq 80 \%$ ). A teljes metszet átlagos pontszámát a festődés intenzitása és a területi pontszám szorzata adta (0-12).

\section{Terminális dezoxinukleotid-transzferáz-} mediált dUTP láncvég jelölés (TUNEL)

A myocardium metszetek TUNEL-festését gyártói protokoll alapján végeztük. Megszámoltuk a TUNEL-pozitív sejtmagokat és az összes sejtmagot (4 vizsgálati területen metszetenként), amelyből egy átlag arányt számoltunk. Az adatokat a megfelelő kontrollcsoportok értékeihez viszonyítottuk.

\section{Génexpressziós vizsgálatok}

A myocardium teljes RNS-készletét izoláltuk, majd reverz transzkripciót követően a cDNS-mintákból kvantitatív valós idejü polimeráz láncreakció során különböző
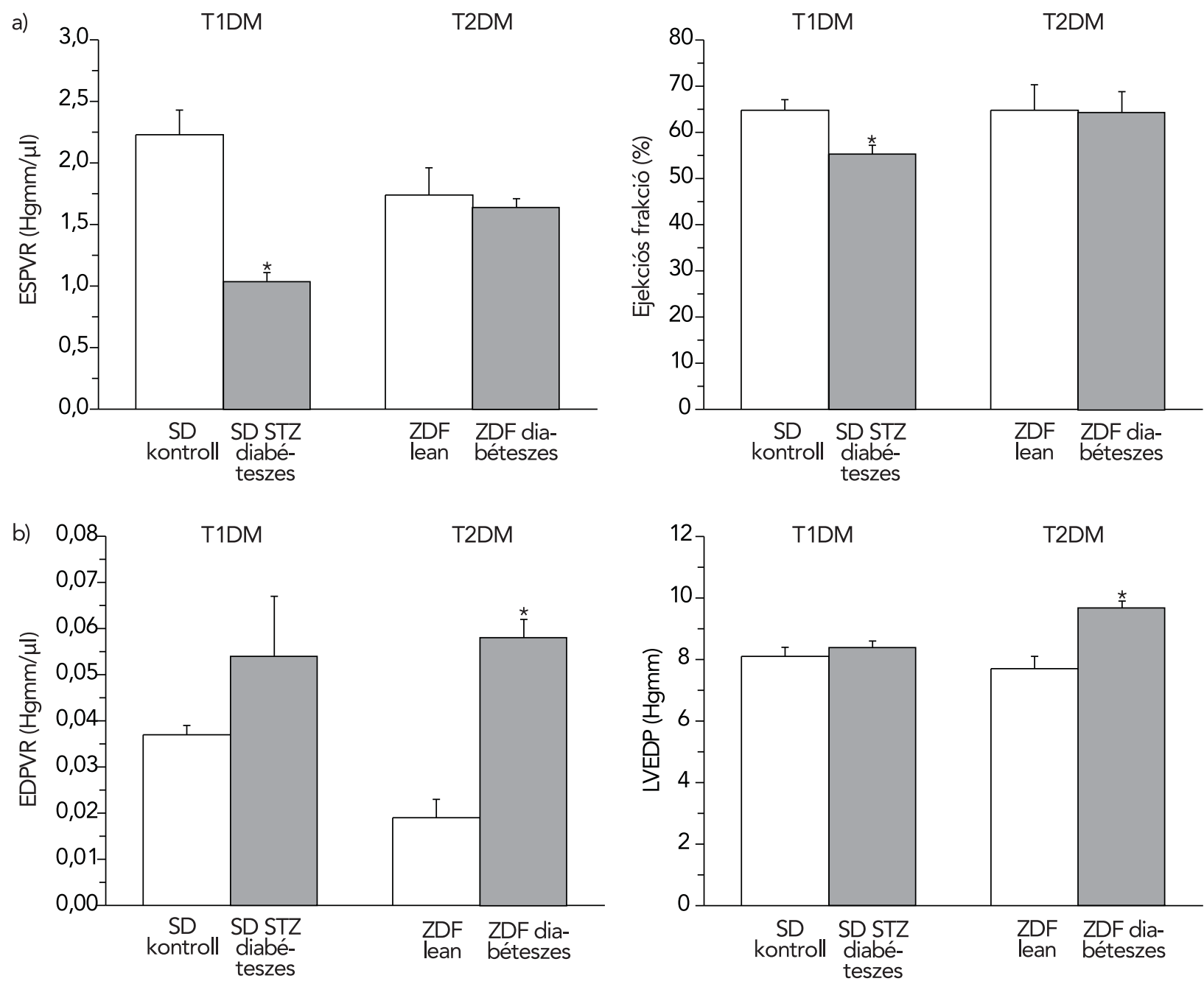

1. ÁBRA. A szív-diszfunkció különböző sajátosságai a T1DM- és T2DM-modellek esetén. Bal kamrai kontraktilitás paraméterek a: végszisztolés nyomás-térfogat összefüggés meredeksége (ESPVR) és ejekciós frakció (EF) az SD-kontroll, STZ-indukálta diabétesz SD (SD STZ diabéteszes), ZDF lean és ZDF diabéteszes patkányok csoportjaiban. A bal kamrai falmerevség paraméterei; b: végdiasztolés nyomás-térfogat összefüggés (EDPVR) és végdiasztolés nyomás (LVEDP) az SD-kontroll, STZ-indukálta diabétesz SD (SD STZ diabéteszes), ZDF lean és ZDF diabéteszes patkányok csoportjaiban. A cukorbetegek és a kontrollok közötti százalékos eltérést mindkét diabétesz modell esetén jeleztük. *: $p<0,05$ vs. a megfelelő nem diabéteszes csoport 
gének expresszióját vizsgáltuk: kataláz, glutation-reduktáz (GSR), szuperoxid-diszmutáz 1 és 2 (SOD1, SOD2), tioredoxin, pitvari nátriuretikus faktor (ANF), alfa és béta-miozin nehézlánc kináz ( $\alpha-\mathrm{MHC}, \beta-\mathrm{MHC})$, kaszpáz-12, kollagén-1, kollagén-3, c-fos, c-jun, endotheliális nitrogén-monoxid-szintáz (eNOS), endotelin-1 (ET-1). Az endogén antioxidánsok esetében adatainkat a gliceraldehid-3-foszfát-dehidrogenáz (GAPDH) expressziójára, míg a többi vizsgált gén esetén a ß-aktin expressziójára normalizáltuk. Eredményeinket a kontrollállatok génexpressziós értékeire vonatkoztattuk.

\section{Western Blot (WB)}

Miokardiális proteinek extrakcióját követően WB-technikát alkalmaztunk a fehérjék szétválasztására, amely során a blotokat transzformáló növekedési faktor béta-1 (TGFß1) specifikus antitestekkel reagáltattuk. A blotot kemilumineszcens módszerrel hívtuk elő. A blot denzitásokat a kontrollcsoporthoz viszonyítottuk.

\section{Statisztikai analízis}

Minden adatot átlag $\pm S E M$ formájában adtuk meg. Párosítatlan kétoldalú t-tesztet használtunk a diabéteszes és kontrollcsoportok összehasonlítására. $A p<0,05$ értéket tekintettük statisztikailag szignifikánsnak.

\section{Eredmények}

\section{Szívtömeg, testtömeg és vércukorszint}

Mindkét modellben magasabb vércukorszintet mértünk a kontrollokhoz képest (T1DM: 26,08 $\pm 0,87$ vs.

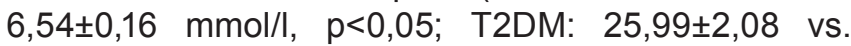
$6,28 \pm 0,29 \mathrm{mmol} / \mathrm{l}, \mathrm{p}<0,05)$. A vizelet glükózteszt mindkét cukorbetegségben pozitívnak bizonyult. A szívtömeg-testtömeg (HW/BW; g/kg) arány T2DM esetében

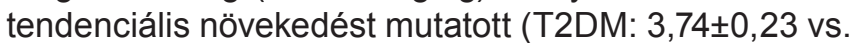
$3,46 \pm 0,05)$, azonban a statisztikai szignifikancia szint-

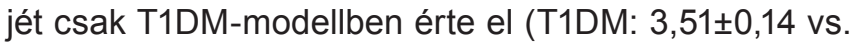
$2,92 \pm 0,06, p<0,05)$.
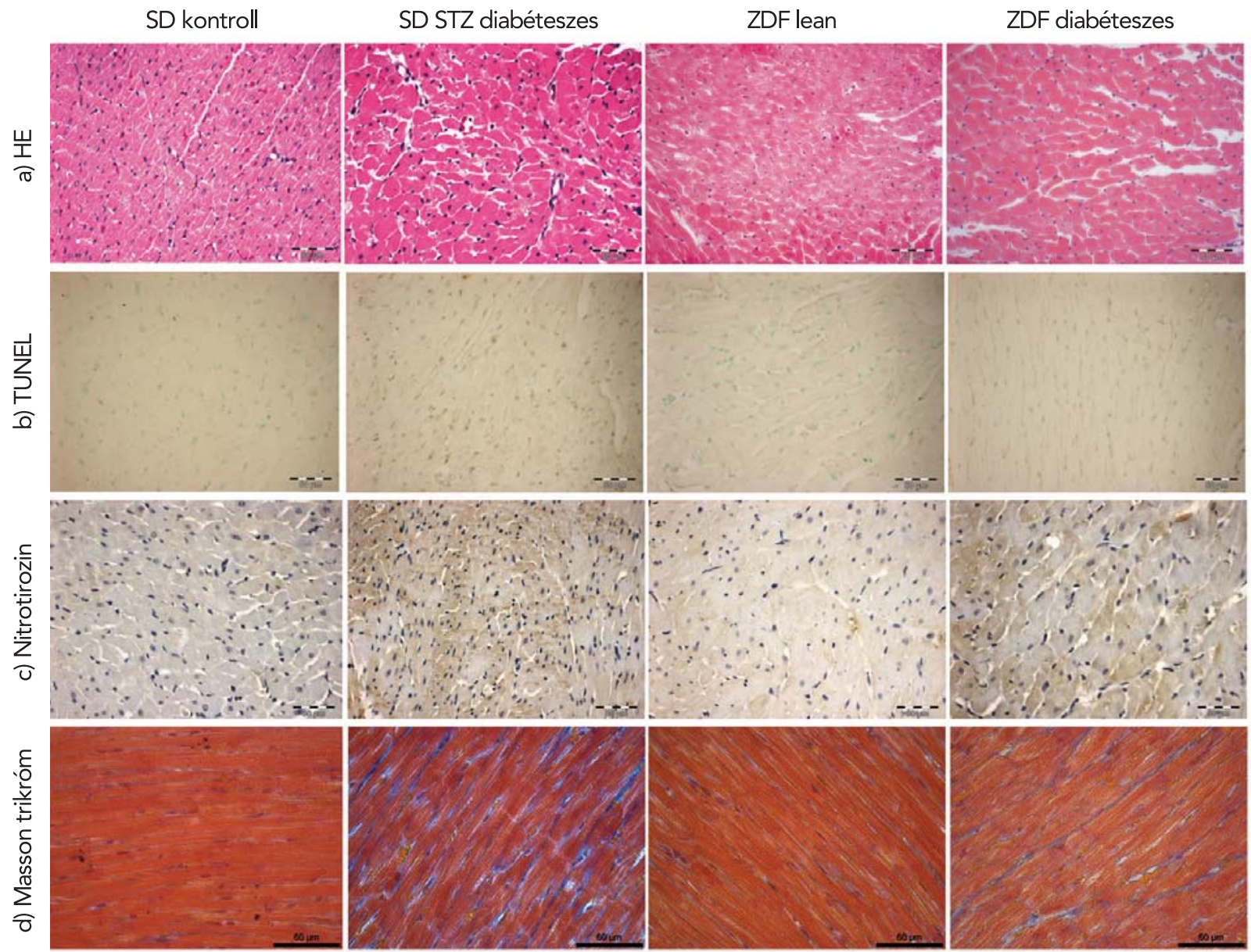

2. ÁBRA. A szív karakterisztikus hisztopatológiai változásai a T1DM- és T2DM-modellek esetén. Reprezentatív szövettani képek a csoportok állatainak bal kamrájából. a: hematoxilin-eozin (HE) festés; skála: 50 m; b: TUNEL-festés apoptózis kimutatására (barna sejtmagok, skála: $50 \mu \mathrm{m}$ ), c: a nitro-oxidatív stresszmarker nitrotirozin immunhisztokémiai festése (barna festődés, skála: $50 \mu \mathrm{m})$ és d: Masson trikróm festés a fibrózis detektálására (kék festődés, skála: 60 m). 
e)

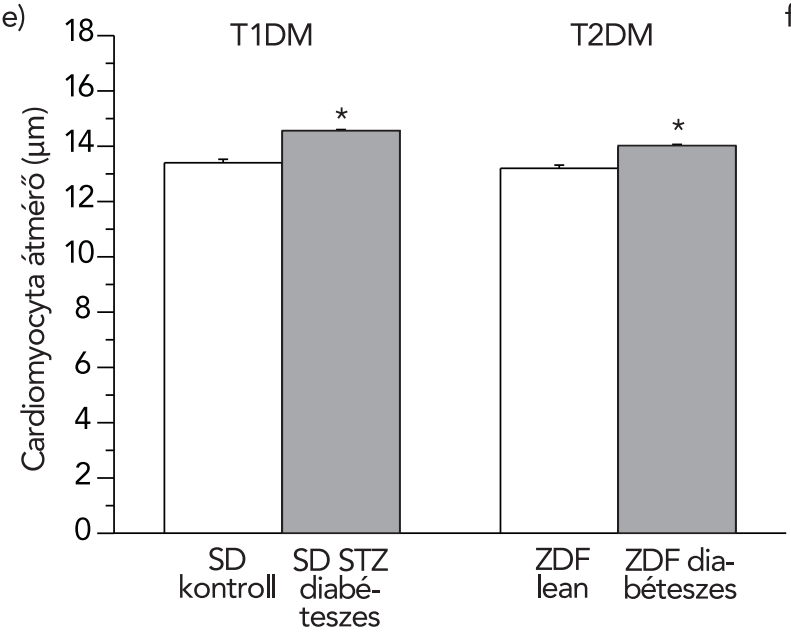

f)

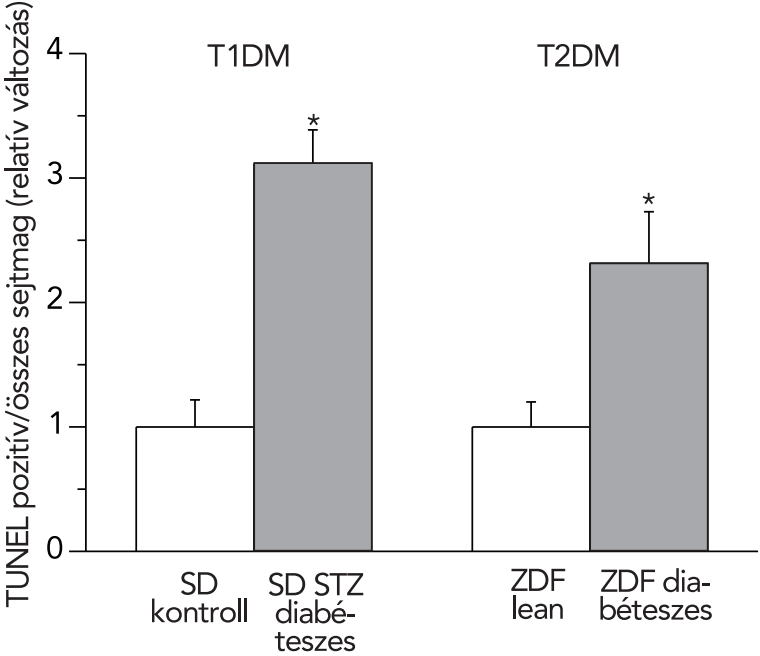

h)

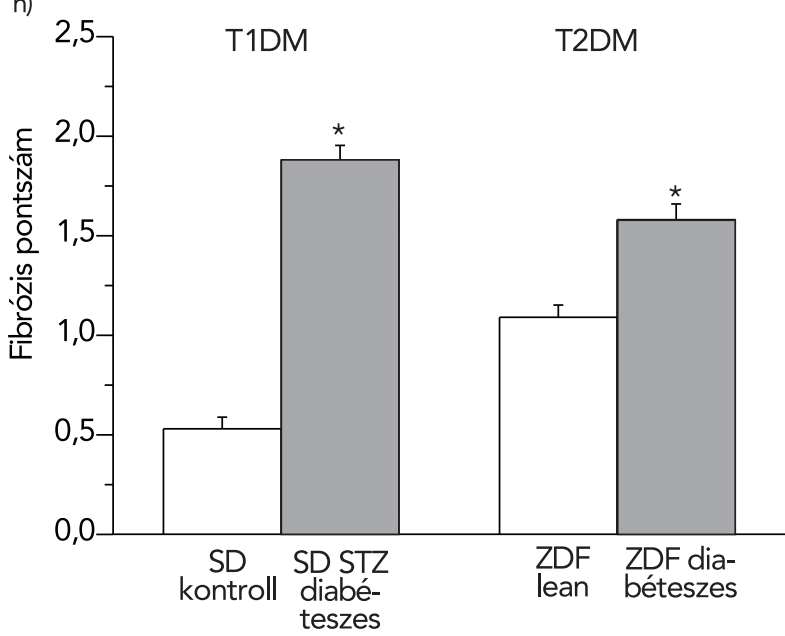

2. ÁBRA. A szív karakterisztikus hisztopatológiai változásai a T1DM- és T2DM-modellek esetén. Reprezentatív szövettani képek a csoportok állatainak bal kamrájából. e: Cardiomyocyta átmérő (hipertrófia marker) kvantifikálása, f: TUNEL-pozitív/összes szívizomsejt arány, g: nitrotirozin immunhisztokémia szemikvantitatív hisztomorfológiai elemzésének eredménye, h: Masson trikróm fibrózis festés kiértékelése. Csoportok: SD-kontroll, STZ-indukálta diabétesz SD (SD STZ diabéteszes), ZDF lean és ZDF diabéteszes állatok. A cukorbetegek és a kontrollok közötti százalékos eltérést mindkét diabétesz modell esetén jeleztük. *: $p<0,05$ vs. a megfelelő nem diabéteszes csoport

\section{Hemodinamika}

A kontraktilitás paraméterei (EF és az ESPVR meredeksége) szignifikánsan alacsonyabbak voltak T1DMben a kontrollértékekhez viszonyítva, amely szisztolés diszfunkcióra utal. Ezzel szemben T2DM esetén a BK-i kontraktilitás változatlan maradt (1. a ábra).

Az LVEDP és az EDPVR meredeksége szignifikánsan magasabb volt a T2DM állatokban, ami a BK falmerevségének fokozódását jelzi. Ezen változások kisebb mértékủek voltak T1DM-ben (1. b ábra).

\section{Szövettan}

HE-festéssel kimutathatók voltak a diabéteszes cardiomyopathia jellegzetes elváltozásai a cukorbetegcsoportok BK-i metszeteiben (2. a ábra). Mindkét DM-modell BK-metszetében megfigyelhető volt az izomrostok rendezetlensége és szétesése, illetve a szívizomzat degenerációja. A KD, amely a szívizom-hipertrófia markere, szignifikánsan magasabbnak bizonyult mindkét DM-modell esetén (2. e ábra).

\section{DNS-lánctörések és nitro-oxidatív stressz}

A kontrollokhoz képest a DM-szívekben emelkedett a TUNEL-pozitivitás, amely a DNS fragmentációjára utal (2. b, fábra) és magasabb volt az NT elleni immunreaktivitás (2. c, g ábra). A TUNEL-pozitivitás és a nitro-oxidatív stressz kifejezettebb volt T1DM esetén T2DM-hez viszonyítva (2. $f, g$ ábra). A SOD1, kataláz, GSR és tioredoxin génexpressziója emelkedett volt T1DM-ben. Ezen változások kevésbé voltak kifejezettek T2DM esetén. A SOD2 mRNS expressziója nem különbözött a csoportok között (3. b ábra). 


\section{Miokardiális fibrózis}

A myocardium fibrotikus remodellációja szignifikánsan kifejezettebb volt T1DM modellben T2DM-hez képest (2. $d$ és $h$ ábra). Az MT-festés szemikvantitatív pontozása jelentős különbségeket mutatott a $B K$ fibrotikus remodellációjában a két DM-modell között (2. $h$ ábra).

\section{Génexpressziós vizsgálatok}

Az a-MHC mRNS-szintje szignifikánsan kisebb, míg a ß-MHC és ET-1 mRNS-szintje magasabb volt mindkét DM-csoportban (3. ábra). Míg a c-fos, c-jun és kaszpáz-12 gének expressziója szignifikáns mértékben emelkedett, addig a kollagén-1, kollagén-3 és az endotheliális NOS expressziója csökkent T1DM esetén a

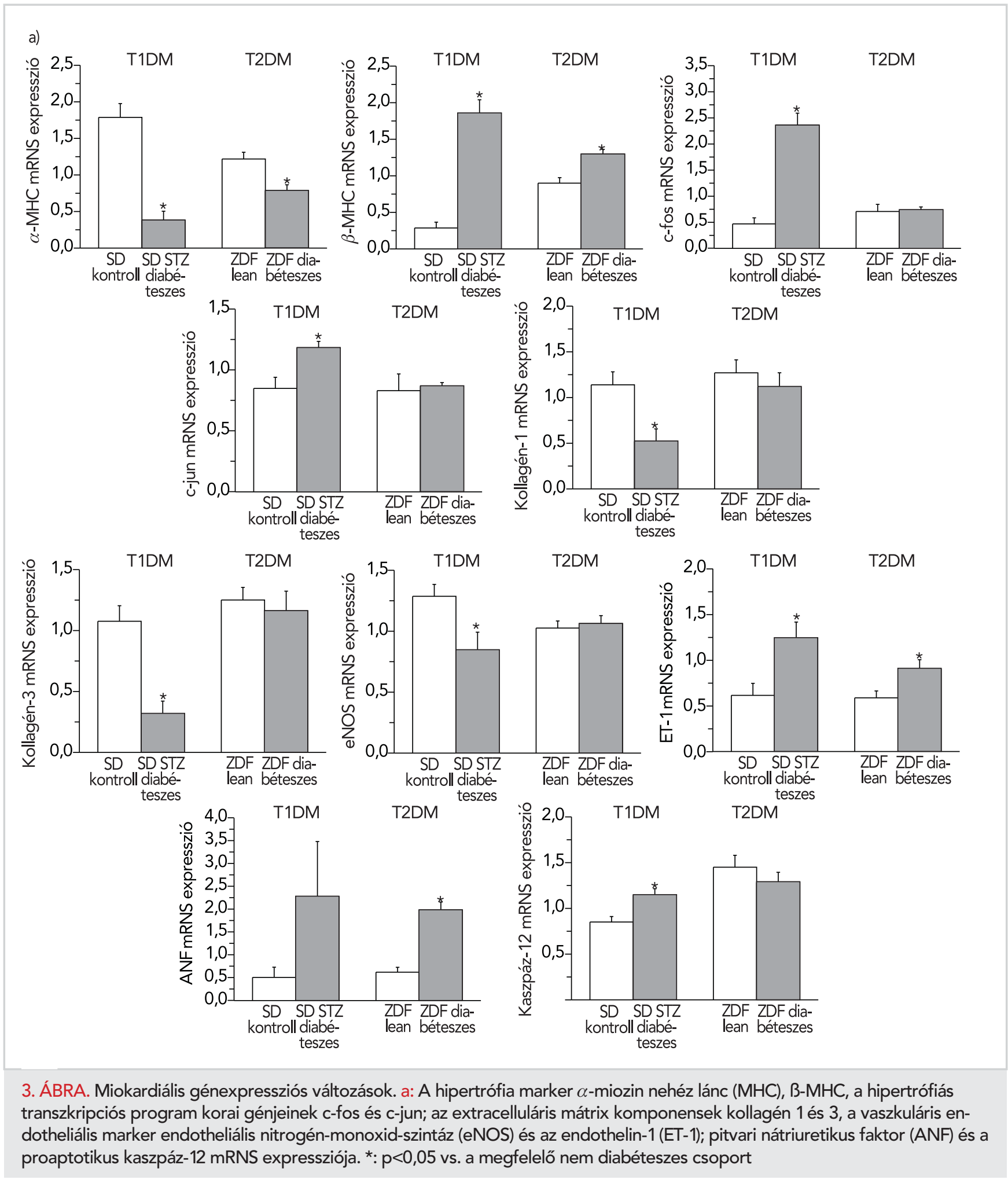



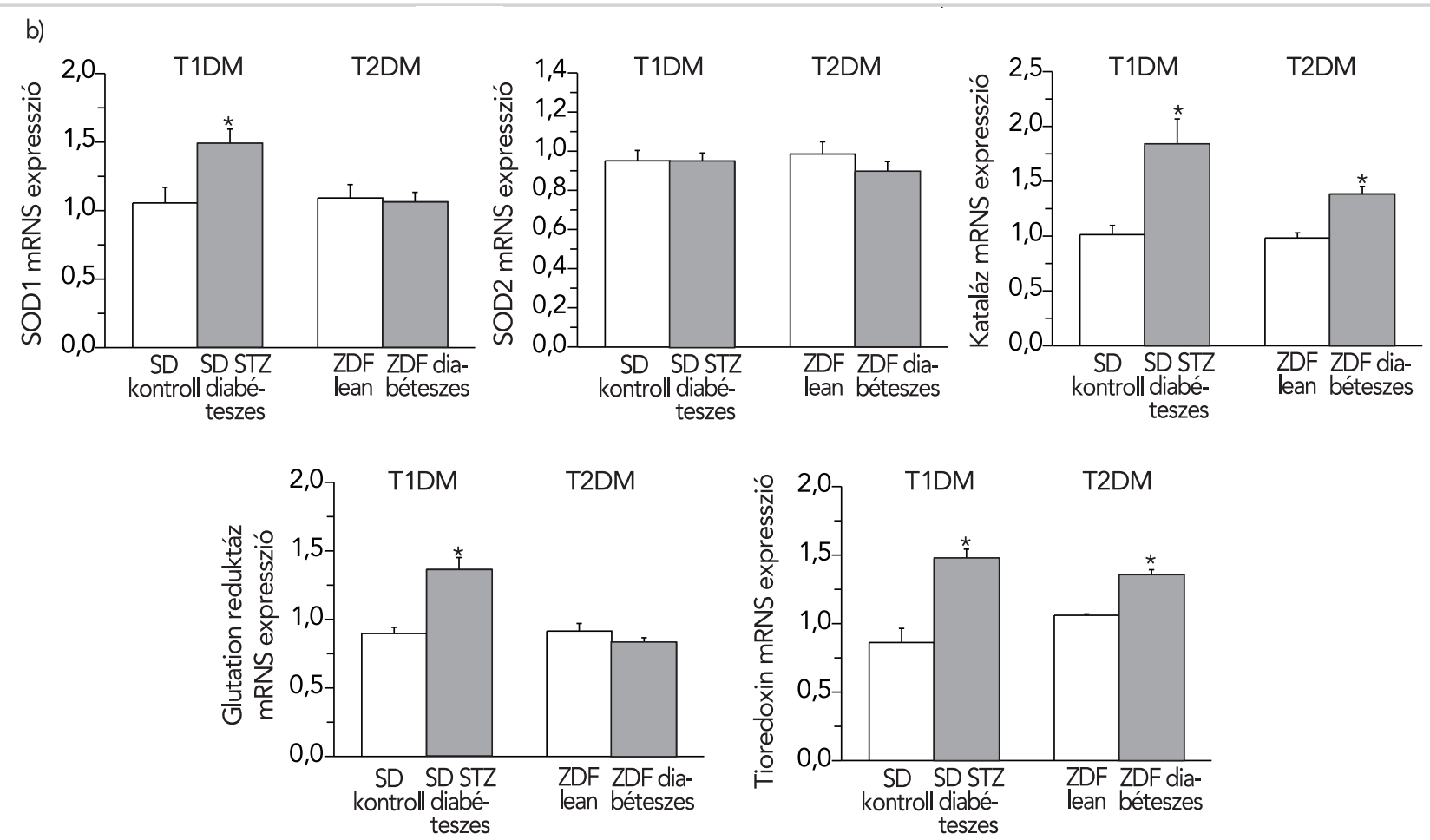

3. ÁBRA. Miokardiális génexpressziós változások. b: Az endogén antioxidáns szuperoxid dizmutáz 1 (SOD1) és 2 (SOD2), kataláz, glutation reduktáz és tioredoxin génexpressziója. Csoportok: SD kontroll, STZ-indukálta diabétesz SD (SD STZ diabéteszes), ZDF lean és ZDF diabéteszes állatok. A cukorbetegek és a kontrollok közötti százalékos eltérést mindkét diabétesz modell esetén jeleztük. *: $p<0,05$ vs. a megfelelő nemdiabéteszes csoport.

kontrollokhoz képest (3. ábra). Az ANF szintje mindkét DM-csoportban megnövekedett, amely azonban csak T2DM esetén bizonyult szignifikánsnak (3. ábra). Az említett gének kifejeződése jelentősebb volt T1DM esetén a T2DM-hez képest (3. ábra).

\section{A TGF-ß1 WB analízise}

A TGF-ß1 szintje szignifikáns emelkedést mutatott T1DM esetében a kontrollokhoz képest, míg T2DM esetén alacsonyabb volt (4. ábra).
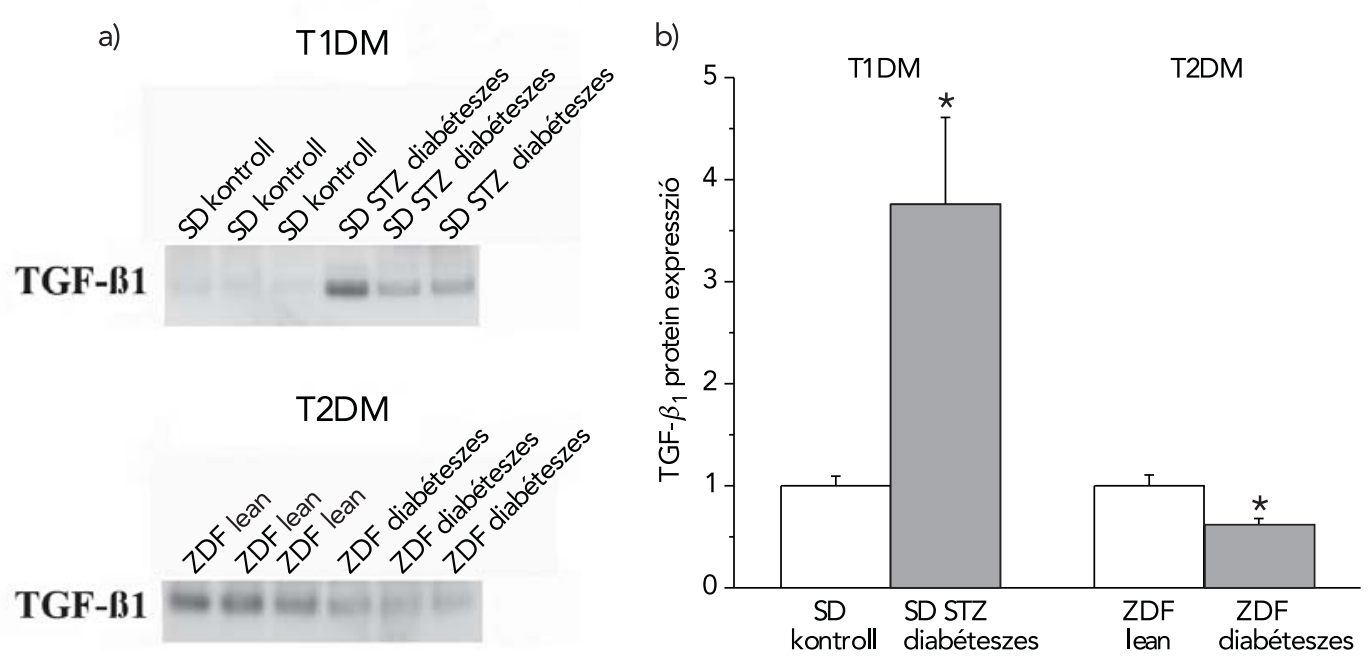

4. ÁBRA. A transzformáló növekedési faktor (TGF)-ß1 miokardiális protein expressziója 1-es és 2-es típusú cukorbetegségben. a: A profibrotikus mediátor TGF-ß1 reprezentatív immunoblotjainak analízise bal kamrai mintából; b: Relatív miokardiális TGF-ß1 protein denzitásértekek a vizsgálati csoportokban. Csoportok: SD-kontroll, STZ-indukálta diabétesz SD (SD STZ diabéteszes), ZDF lean és ZDF diabéteszes állatok. A cukorbetegek és a kontrollok közötti százalékos eltérést mindkét diabétesz modell esetén. *: $p<0,05$ vs. a megfelelő nem diabéteszes csoport. 


\section{Megbeszélés}

Jelen tanulmányunkban az 1-es és a 2-es típusú cukorbetegségben kialakuló diabéteszes cardiomyopathia funkcionális, szövettani és molekuláris eltéréseit hasonlítottuk össze. A két cukorbeteg modell között leírt funkcionális különbségeket megváltozott miokardiális gén- és fehérje-expresszió, továbbá megnövekedett nitro-oxidatív stressz, szívizom-hipertrófia valamint kötőszöveti remodelláció kísérte. A diabéteszes cardiomyopathia kiemelkedő klinikai fontossága ellenére a myocardium strukturális és funkcionális változásainak hátterében álló sejtszintű és molekuláris faktorok szerepe ezidáig nem teljesen tisztázott. Az oxidatív egyensúly megbomlása, a megnövekedett nitro-oxidatív stressz, a szívizomsejtek apoptózisa valamint a miokardiális hipertrófia és fibrotikus remodelláció valószínűsíthetően központi szerepet játszik a DM kardiális szövődményeinek kialakulásában (9).

Az NT immunhisztokémiai festése, amely a nitro-oxidatív stressz egyik markere, a cukorbeteg szívizomban emelkedett immunreaktivitást mutatott mindkét DM-modell esetén, amely megfigyelés összhangban áll korábbi tanulmányok eredményeivel $(13,14)$. A festés szemikvantitatív analízise alapján T1DM-ben kifejezettebb nitro-oxidatív stressz dokumentálható a T2DM-hez képest. Az endogén antioxidáns rendszerek expreszsziójának kompenzatorikus megnövekedése (SOD, kataláz, glutation és tioredoxin enzimrendszerek) T1DMben további bizonyítéka a jelentősen megnövekedett nitro-oxidatív stressznek. Az emelkedett nitro-oxidatív stressz különféle jelátviteli pályákat indíthat el, amelyek következménye lehet apoptózis, a myocardium hipertrófiája és kötőszöveti átalakulása (9).

Az apoptózis felerősödése számos szív- és érrendszeri betegség patológiai hátterében áll, beleértve a diabéteszes cardiomyopathiát. Egyre növekvő számú klinikai és experimentális megfigyelés számol be arról, hogy a szívizomsejtek számának progresszív csökkenése fontos kóroki szerepet játszik a diabéteszes cardiomyopathia kialakulásában $(8,9,15)$. A cardiomyocyták apoptózisa hozzájárul a cukorbeteg szív dekompenzálódásához (16), mivel az elhalt szívizomsejtek helyébe extracelluláris mátrix komponensek lépnek, amely kollagén felhalmozódáshoz és miokardiális fibrózishoz vezet $(17,18)$. TUNEL-módszerrel felmérhető a DNS-törések és fragmentációk jelenléte, így detektálhatók az apoptotikus sejtek (19). Összhangban korábbi irodalmi adatokkal $(15,20)$, jelen eredményeink fokozott apoptózist mutatnak a cukorbeteg állatok szívizomzatában (megnövekedett a TUNEL-pozitív cardiomyocyta magok száma, valamint a proapoptotikus mediátor kaszpáz-12 miokardiális expressziója), amely T1DM esetében markánsabbnak bizonyult.

Mindkét állatmodellünkben jelentős miokardiális hipertrófia alakult ki (a szívizomsejtek átmérője szignifikánsan emelkedett). T2DM-ben a szívtömeg/testtömeg arány emelkedő tendenciát mutatott, amely ugyanakkor szignifikáns T1DM-állatok esetén volt. Mindazonáltal szívtömeg/testtömeg arányt nagymértékben befolyásolja a testtömeg ingadozása (amely sokkal kifejezettebb volt a T1DM-modell esetén). Szívizom-hipertrófia során az azonnali-korai gének, úgy, mint a c-jun és c-fos, átmenetileg aktiválódnak, ami különböző patológiás molekuláris jelátviteli utak fokozódásához vezet $(21,22)$. Ezen gének expressziójának emelkedése a T1DM-állatok esetében bizonyult szignifikánsnak. A c-jun és c-fos aktiválják a fötális génprogramot (a ß-MHC vagy ANF-gének transzkripciója), amelyek kitüntetett szerepet játszanak az adaptív hipertrófiában és a szívizomsejtek maladaptív elváltozásaiban (23). $\mathrm{Az} \alpha-\mathrm{MHC}$ csökkent, továbbá a fötális típusú ß-MHC megnövekedett expressziója, mint a patológiás hipertrófia molekuláris markerei, mindkét DM-modellben megfigyelhető volt, azonban változásuk a T1DM-állatokban kifejezettebb volt. A két DM-modellben hasonló volt az ANF-hipertrófia marker expressziójának mértéke. Korábbi kutatási eredményekkel összhangban jelen vizsgálatunkban is igazoltuk, hogy a diabéteszhez társuló szívizom-hipertrófia mindkét DM esetén kialakul $(9,24,25)$.

A myocardium kötőszövetes, fibrotikus remodellációja egy másik kulcspontja a diabéteszes cardiomyopathia kórélettanának. A profibrotikus jelátvitel fokozódása és az intersticiális kollagén-lerakódás hátterében a reaktív oxigén- és nitrogéngyökök fokozott termelődése (9), továbbá az apoptotikus szívizomsejt-elhalás állhat. Kifejezettebb nitro-oxidatív stressz és apoptózis, továbbá a profibrotikus mediátor TGF-ß1 miokardiális szintjének markáns emelkedése, valamint szignifikánsan magasabb szövettani fibrózis pontszámok igazolhatók a T1DM-patkányokban (fibrózis + 260\%) a T2DM-állatokhoz (fibrózis + 45\%) képest. Habár a miokardiális fibrózis kialakulása az STZ-indukálta T1DM-modellben széles körben ismert és dokumentált $(9,25,26)$, T2DM esetében mindez vitatott. Marsh és munkatársai nem találtak miokardiális kollagén-lerakódást 14 hetes ZDF-állatokban (27); más tanulmányok mindössze perivaszkuláris fibrózist dokumentáltak, az intersticiális kötőszövet felhalmozódása nélkül 19 hetes állatokban (24), míg 45 hetes ZDF-patkányokban a bal kamra intenzív fibrotikus remodellációját dokumentálták (28). Ezen eltérések hátterében az állatok eltérő kora, vagyis a cukorbetegség fennállásának eltérő hossza állhat. Jelen eredményeink, amelyek a miokardiális intersticiális fibrózis pontszám 45\%-os emelkedését mutatják 30-32 hetes ZDF-patkányokban összhangban állnak a szakirodalmi adatokkal. Érdekes módon T1DM-ben, a jelentősen rövidebb diabéteszes időtartam (8 hét) sokkal súlyosabb szívizom-fibrózishoz vezet, mint T2DM esetében (30-32 hetes életkor megfelel 23-25 hetes cukorbeteg időtartamnak). Bár a cukorbetegség súlyossága (hyperglykaemia mértéke) vizsgálatunk során hasonlónak bizonyult, a kórélettani/metabolikus kü- 
lönbségek (csökkent inzulinszint vs. hyperinsulinaemia és inzulinrezisztencia az első fázisban) valamint a DM eltérő időtartama a betegség két típusában magyarázhatja ezen jelenséget. Korábbi eredményekkel összhangban (28) a cukorbeteg szívizomzat Masson trikróm-festéssel detektált emelkedett fibrózis pontszám értékei a kollagén 1 és 3 csökkent mRNS expressziójával jártak. Valószínűleg a megfigyelt intersticiális fibrózis hátterében a kollagén lebomlási ütemének módosulása, és nem annak emelkedett szintézise áll.

Fentiek mellett, a diabéteszes cardiomyopathia kialakulásának hátterében a szív mikrovaszkulatúrájának endotheliumából felszabaduló vazoaktív ágensek, úgy mint az ET-1 és az NO, szintjének változása is kóroki szerepet játszik (29). Vizsgálatunkban jelentősen emelkedett ET-1-expressziót detektáltunk mindkét DM-modell szívizomzatában (amely a T1DM esetén kifejezettebb volt), míg az eNOS csökkent expressziója csak T1DM esetén volt megfigyelhető. Eredményeink a szív súlyosabb mikrovaszkuláris károsodását mutatják T1DM esetében T2DM-hez viszonyítva. Az ET-1 megemelkedett szintje cukorbetegségben kapcsolatban állhat a myocardium fibrotikus átalakulásával, mivel az ET-1 által indukált endothel-mesenchyma átalakulás fibroblasztok felszaporodásához vezethet (30).

A diabéteszes szívben leírt funkcionális változások szoros kapcsolatban állnak a szívizomsejt-hipertrófia, az apoptózis és a fibrózis molekuláris és szövettani elváltozásaival (9). Ezen három fő komponens hozzájárulása a diasztolés (szívelégtelenség megtartott ejekciós frakcióval [HFpEF]) vagy a szisztolés diszfunkcióhoz valamennyire eltérhet. HFpEF esetében mind a szívizomsejt-hipertrófia, mind a miokardiális fibrózis jelen van, azonban az utóbbi - a szívizomsejtek emelkedett apoptózisával együtt - kifejezettebb szisztolés szívelégtelenség esetében $(9,17,18)$. A DM-hez társult HFpEF-fel szemben DM-ben megfigyelhető szisztolés diszfunkció kialakulásában számottevő szerepet játszhat a cardiomyocyták által termelt ROS, cardiomyocyta apoptózis és a következményes extracelluláris mátrix lerakódás és fibrotikus remodelláció $(17,31)$. Bár jelen kutatásunkban nem vizsgáltuk, további molekuláris mechanizmusok (úgy, mint az elörehaladott glikációs végtermékek [AGE] lerakódása, kollagén keresztkötés, továbbá a szarkomer fehérjék oxidatív módosulásai) is hozzájárulhatnak a diasztolés diszfunkció kialakulásához a cukorbeteg állatokban.

A fent leírt kórélettani változásokkal összhangban, korábbi méréseink (6) és jelen eredményeink az in vivo myocardium funkció (bal kamrai PV-analízis) tekintetében összevethető különbségeket mutatnak az 1-es és 2-es típusú diabéteszes modell kardiális diszfunkciója terén. A bal kamrai kontraktilitás jelentős romlása és a szisztolés diszfunkció (csökkent EF és ESPVR) csak T1DM-ben volt kimutatható, amelyet súlyos nitro-oxidatív stressz, apoptózis és miokardiális fibrózis kísért. A T1DM-modellel szemben ezen patológiás elváltozások enyhébbek voltak vagy hiányoztak T2DM esetén, míg a cardiomyocyta-hipertrófia mértéke hasonló volt a két DM-típus között. ZDF cukorbeteg patkányokban kifejezett diasztolés falmerevség (megnövekedett LVEDP és EDPVR) és megtartott szisztolés funkció (amely jellemző a HFpEF-re) volt megfigyelhető. Eredményeink alapján a DM két típusa közötti eltérő kórélettani háttér, súlyosság és progresszió lehet a kulcsa a diabéteszes cardiomyopathiában megfigyelt funkcionális illetve molekuláris különbségeknek T1DM és T2DM esetében.

A krónikus szívelégtelenség klinikai ellátása és terápiája során egyre inkább előtérbe kerül a betegek különböző komorbiditásainak (pl. cukorbetegség) ismerete és figyelembe vétele. A vizsgálatunkban alkalmazott állatmodellek hüen reprezentálják az emberekben kialakuló két típusú cukorbetegség patofiziológiáját és kórlefolyását. Ugyanakkor, modellrendszerek lévén a belölük nyert kísérleti adatok korlátozásokkal ültethetőek át a klinikai környezetbe. Mindazonáltal, eredményeink hozzájárulhatnak a klinikai körülmények között cukorbetegekben megfigyelhető krónikus szívelégtelenség patomechanizmusának pontosabb megértéséhez és új terápiás lehetőségek kifejlesztéséhez.

Jelen közlemény Tamás Radovits, Sevil Korkmaz, Csaba Mátyás, et al. "An Altered Pattern of Myocardial Histopathological and Molecular Changes Underlies the Different Characteristics of Type-1 and Type-2 Diabetic Cardiac Dysfunction". Journal of Diabetes Research vol. 2015, Article ID 728741, 12 pages, 2015. doi.10.1155/2015/728741 közleményének (32) felhasználásával készült a Hindawi Publishing Corporation engedélye (Creative Commons Attribution License) alapján.

Jelen munkánkat a Magyar Tudományos Akadémia Bolyai János Kutatási Ösztöndíja (R.T.), az Országos Tudományos Kutatási Alapprogramok PD100245 programja (R.T.) és a Nemzeti Kutatási, Fejlesztési és Innovációs Hivatal - NKFIH (NVKP-16-1-2016-0017, Nemzeti Szívprogram, M.B.) támogatta.

\footnotetext{
Irodalom

1. Boudina S, Abel ED. Diabetic cardiomvopathy revisited. Circulation 2007; 3213-23. Doi 10.1161/CIRCULATIONAHA.106.679597

2. An D, Rodrigues B. Role of changes in cardiac metabolism in development of diabetic cardiomyopathy. Am J Physiol Heart Circ Physiol 2006: H1489-506. Doi 10.1152/ajpheart.00278.2006

3. Rees DA, Alcolado JC. Animal models of diabetes mellitus. Diabet Med 2005; 359-70. Doi 10.1111/j.1464-5491.2005.01499.x

4. Guleria RS, Singh AB, Nizamutdinova IT, et al. Activation of retinoid receptor-mediated signaling ameliorates diabetes-induced cardiac dysfunc tion in Zucker diabetic rats. J Mol Cell Cardiol 2013; 106-18. Doi 10.1016/j. yjmcc.2013.01.017

5. Mansor LS, Gonzalez ER, Cole MA, et al. Cardiac metabolism in a new rat model of type 2 diabetes using high-fat diet with low dose streptozotocin. Cardiovasc Diabetol 2013; 136. Doi 10.1186/1475-2840-12-136

6. Radovits T, Korkmaz S, Loganathan S, et al. Comparative investigation of the left ventricular pressure-volume relationship in rat models of type 1 and type 2 diabetes mellitus. Am J Physiol Heart Circ Physiol 2009; H125-33. Doi 10.1152/ajpheart.00165.2009

7. Aragno M, Mastrocola R, Alloatti G, et al. Oxidative stress triggers
} 
cardiac fibrosis in the heart of diabetic rats. Endocrinology 2008; 380-8. Doi $10.1210 /$ en.2007-0877

8. Cai L, Kang YJ. Cell death and diabetic cardiomyopathy. Cardiovasc Toxicol 2003; 219-28. Doi 10.1385/CT:3:3:219

9. Huynh K, Bernardo BC, McMullen JR, et al. Diabetic cardiomyopathy: mechanisms and new treatment strategies targeting antioxidant signaling pathways. Pharmacol Ther 2014; 375-415. Doi 10.1016/j.pharmt hera.2014.01.003

10. Radovits T, Bomicke T, Kokeny G, et al. The phosphodiesterase- 5 inhibitor vardenafil improves cardiovascular dysfunction in experimental diabetes mellitus. Br J Pharmacol 2009; 909-19. Doi 10.1111/j.1476-

\subsection{8 .00098}

11. Pacher P, Nagayama T, Mukhopadhyay P, et al. Measurement of cardiac function using pressure-volume conductance catheter technique in mice and rats. Nat Protoc 2008; 1422-34. Doi 10.1038/nprot.2008.138

12. Liaudet L, Soriano FG, Szabo E, et al. Protection against hemorrhagic shock in mice genetically deficient in poly(ADP-ribose)polymerase. Proc Natl Acad Sci U S A 2000; 10203-8. Doi 10.1073/pnas.170226797

13. Kajstura J, Fiordaliso F. Andreoli AM, et al. IGF-1 overexpression inhibits the development of diabetic cardiomyopathy and angiotensin II-mediated oxidative stress. Diabetes 2001; 1414-24. Doi 10.2337/di-

\subsection{4}

14. Song D, Kuo KH, Yao R, et al. Inducible nitric oxide synthase depres ses cardiac contractile function in Zucker diabetic fatty rats. Eur J Phar macol 2008; 253-9. Doi 10.1016/j.ejphar.2007.09.043

15. Fiordaliso F, Li B, Latini R, et al. Myocyte death in streptozotocin-induced diabetes in rats in angiotensin II- dependent. Lab Invest 2000 513-27.

16. Frustaci A, Kajstura J, Chimenti C, et al. Myocardial cell death in human diabetes. Circ Res 2000; 1123-32. Doi 10.1161/01.RES.87.12.1123

17. Paulus WJ, Tschope C. A novel paradigm for heart failure with preserved ejection fraction: comorbidities drive myocardial dysfunction and remodeling through coronary microvascular endothelial inflammation. J Am Col Cardiol 2013; 263-71. Doi 10.1016/j.jacc.2013.02.092

18. van Heerebeek L, Hamdani N, Handoko ML, et al. Diastolic stiffness of the failing diabetic heart: importance of fibrosis, advanced glycation end products, and myocyte resting tension. Circulation 2008; 43-51. Do 10.1161/CIRCULATIONAHA.107.728550

19. LOO DT. In situ detection of apoptosis by the TUNEL assav. an ove view of techniques. Methods Mol Biol 2011; 3-13. 60327-409-8_1

20. Ramirez E, Klett-Mingo M, Ares-Carrasco S, et al. Eplerenone attenuated cardiac steatosis, apoptosis and diastolic dysfunction in experimental type-II diabetes. Cardiovasc Diabetol 2013; 172. Doi 10.1186/1475-2840-12-172

21. Min W, Bin ZW, Quan ZB, et al. The signal transduction pathway of PKC/NF-kappa B/c-fos may be involved in the influence of high glucose on the cardiomyocytes of neonatal rats. Cardiovasc Diabetol 2009; 8 . Doi 10.1186/1475-2840-8-8

22. Nadruz W, Jr., Corat MA, Marin TM, et al. Focal adhesion kinase mediates MEF2 and c-Jun activation by stretch: role in the activation of the cardiac hypertrophic genetic program. Cardiovasc Res 2005; 87-97. Doi 10.1016/j. cardiores.2005.05.011

23. Cox EJ, Marsh SA. A systematic review of fetal genes as biomarkers of cardiac hypertrophy in rodent models of diabetes. PLoS One 2014 e92903. Doi 10.1371/journal.pone.0092903

24. Fredersdorf S, Thumann C, Ulucan C, et al. Myocardial hypertrophy and enhanced left ventricular contractility in Zucker diabetic fatty rats Cardiovasc Pathol 2004; 11-9. Doi 10.1016/S1054-8807(03)00109-1 25. Xia Z, Kuo KH, Nagareddy PR, et al. N-acetylcysteine attenuates PKCbeta2 overexpression and myocardial hypertrophy in streptozotocin-induced diabetic rats. Cardiovasc Res 2007; 770-82. Doi 10.1016/j.

\section{cardiores.2006.11.033}

26. Taye A, Abouzied MM, Mohafez OM. Tempol ameliorates cardiac fibrosis in streptozotocin-induced diabetic rats: role of oxidative stress in diabetic cardiomyopathy. Naunyn Schmiedebergs Arch Pharmacol 2013 1071-80. Doi 10.1007/s00210-013-0904-x

27. Marsh SA, Powell PC, Agarwal A, et al. Cardiovascular dysfunction in Zucker obese and Zucker diabetic fatty rats: role of hydronephro sis. Am J Physiol Heart Circ Physiol 2007; H292-8. Doi 10.1152/ajpheart.01362.2006

28. Daniels A, Linz D, van Bilsen M, et al. Long-term severe diabetes only leads to mild cardiac diastolic dysfunction in Zucker diabetic fatty rats. Eur J Heart Fail 2012; 193-201. Doi 10.1093/eurjhf/hfr166 29. Farhangkhoee $\mathrm{H}$, Khan ZA, Kaur H, et al. Vascular endothelial dysfunction in diabetic cardiomyopathy: pathogenesis and potential treatment targets. Pharmacol Ther 2006; 384-99. Doi 10.1016/j.pharmt-

\section{hera.2005.10.008}

30. Widyantoro B, Emoto N, Nakayama K, et al. Endothelial cell-derived endothelin-1 promotes cardiac fibrosis in diabetic hearts through stimulation of endothelial-to-mesenchymal transition. Circulation 2010; 2407 18. Doi 10.1161/CIRCULATIONAHA.110.938217

31. Gonzalez A, Ravassa S, Beaumont J, et al. New targets to treat the structural remodeling of the myocardium. J Am Coll Cardiol 2011; 1833 43. Doi $10.1016 /$ j.jacc.2011.06.058

32. Radovits T, Korkmaz S, Matyas C, et al. An altered pattern of myocardial histopathological and molecular changes underlies the differen characteristics of type-1 and type-2 diabetic cardiac dysfunction. J Diabetes Res 2015; 728-741. Doi 10.1155/2015/728741

\section{Május a vérnyomásmérés hónapja!}

A Nemzetközi Hypertonia Társaság és a Hypertonia Világ Liga mozgalmat hirdetett 2017 májusára

(May Measurement Month 2017 - MMM17).

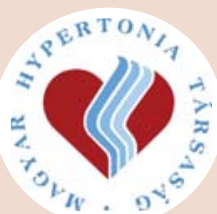

A mozgalom újabb figyelemfelhívás a népbetegséggé vált hypertonia veszélyeire, kellő időben történő felismerésére és megelőzésére. A Egészségügyi Világszervezet minden év május 17-ére hirdeti meg a Hypertonia Világnapját, amely most kiegészül egy egész hónap vérnyomásmérési programjával.

A 3,5 millió hypertóniás beteg miatt Magyarország is jelentkezett a mozgalomba, amelynek során, olyan egyéneknél történik adatlap kitöltés és vérnyomásmérés, akiknél egy éven belül nem volt megmérve a vérnyomása (MMM17-HU Program).

A vérnyomásmérő helyek terveink szerint a Hypertónia Ellátó helyek, a társ-társaságok szakrendelései, a háziorvosi rendelők és a gyógyszertárak, a munkahelyek és a családtagok lesznek. Önkéntesek segítségével közösségi rendezvényeken, bevásárló központokban is sor kerülhet vérnyomásmérésre.

A jelentkezéskor mindenki kódot és a mozgalom dokumentumait kapja meg.

Kérjük, hogy jelentkezésével, támogató és segitő részvételével segítse a mozgalom hazai megvalósulását. Jelentkezni lehet a Nemzeti Koordinátori Iroda címén: mmm17.hu@gmail.com

Prof. dr. Kiss István

az MHT elnöke

a Magyar Hypertonia Társaság vezetősége nevében
Prof. dr. Járai Zoltán

az MHT főtitkára

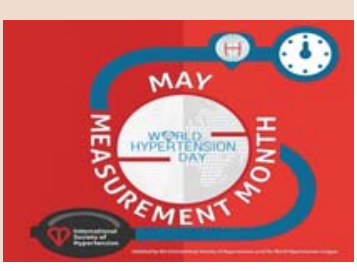

